\title{
Biogeography of the Carpathians: towards a better understanding of biodiversity patterns
}

\author{
Mihai Puşcaş ${ }^{1,2} \cdot$ Michał Ronikier $^{3} \cdot$ Patrik Mráz $^{4} \cdot$ Bogdan-luliu Hurdu ${ }^{5}$
}

Received: 9 March 2021 / Accepted: 10 March 2021 / Published online: 27 March 2021

(c) The Author(s), under exclusive licence to Springer-Verlag GmbH Austria, part of Springer Nature 2021

The Carpathians are one of the most extensive mountain ranges of the European Alpine System (Ozenda 1985) and a widely recognised mountain biodiversity hotspot in Europe (Schmitt 2009; Bálint et al. 2011; Mráz and Ronikier 2016). Additionally, although well-delimited from geomorphological point of view, the Carpathian Region (with its subunits, i.e. the Western, Eastern and Southern Carpathians, the Apuseni Mountains and the Transylvanian Basin) is closely linked through its shared biotic components with the neighbouring mountainous regions of the Alps, the Hercynian Massif, and the Balkan Peninsula (Stevanović 1996; Coldea 2003; Aeschimann et al. 2004; Puşcaş and Choler 2012; Jablonski et al. 2016). Evolution and spatial distribution of taxa and genetic lineages, and assembly of biotic communities in this region, were largely shaped by an interplay of geomorphology, habitat distribution, and past climatic oscillations during the Tertiary and Quaternary, which alternated periods of biotic interchange among regions with periods of increased isolation. The consequences of lineage divergence, as well as the role of both ecological and historical factors in driving evolutionary processes and shaping biogeographical patterns, have become the focal point of burgeoning research

Contribution to "Biogeography of the Carpathians".

Bogdan-Iuliu Hurdu

bogdan.hurdu@icbcluj.ro

1 A. Borza Botanic Garden, Babeş-Bolyai University, 42 Republicii Street, 400015 Cluj-Napoca, Romania

2 Department of Taxonomy and Ecology, Faculty of Biology and Geology, Babeş-Bolyai University, 44 Republicii Street, 400015 Cluj-Napoca, Romania

3 W. Szafer Institute of Botany, Polish Academy of Sciences, Lubicz 46, 31-512 Kraków, Poland

4 Herbarium Collections and Department of Botany, Charles University, Benátská 2, 12801 Prague, Czech Republic

5 Institute of Biological Research, National Institute of Research and Development for Biological Sciences, 48 Republicii Street, 400015 Cluj-Napoca, Romania initiatives over the last decade (reviewed by Ronikier 2011; Mráz and Ronikier 2016), further pursued with numerous recent studies (Šrámková-Fuxová et al. 2017; Wielstra et al. 2017; Jarčuška et al. 2019; Juřičková et al. 2019; Melichárková et al. 2019; Pârvulescu et al. 2019; Tkach et al. 2019; Zając et al. 2020). The ever-increasing scientific interest for the biogeography of the Carpathian Region required a dedicated framework for sharing ideas and results in order to provide a clearer and thorough overview. This led to the establishment of the Biogeography of the Carpathians series of conferences.

The present topical collection of Plant Systematics and Evolution arose from The Second Interdisciplinary Symposium Biogeography of the Carpathians-ecological and evolutionary facets of biodiversity, held on 28-30 September 2017, Cluj-Napoca, Romania. This edition of the symposium was organised within the framework of a long-term international collaboration and continued the idea of the first edition of this meeting initiated and organised in 2013, in Kraków (Poland), which proved successful and timely as an information exchange platform for the scientific community interested in the Carpathian biodiversity (Mráz and Ronikier 2016; abstracts available at https://abcbot.pl/pdf/supp155_1/sup_55_s1.pdf). The central theme and aim of the Cluj-Napoca symposium was to further present and discuss the most recent advances on the biodiversity, biogeography and evolution in the Carpathian region, focused on several topics such as: the historical and ecological biogeography and the drivers of evolution and species assemblages, the Carpathians in a larger biogeographical context, and finally the diversity of Carpathians (from genes to ecosystems) and its conservation. The symposium brought together about 130 scientists from 11 countries (Austria, Czechia, France, Germany, Hungary, Poland, Romania, Serbia, Slovakia, UK and Ukraine), who covered various disciplines, ranging from systematics (plants, animals, algae, fungi, lichens) to ecology, biogeography, palynology or conservation biology. 
Abstracts of all contributions have been published in a special issue of Studia Universitatis Babeş-Bolyai, series Biologia, Volume 62, Special Issue, 2017 (available online at http://studia.ubbcluj.ro/download/pdf/1106.pdf).

The papers published in the Biogeography of the Carpathians topical collection are mostly derived from the presentations given at the meeting. Consequently, they provide a good overview of the latest research carried out in the Carpathian Region, related to the above-mentioned topics. The largest set of papers concerns spatial patterns of diversity including their taxonomical resonance. Skokanová et al. (2019) and Šrámková et al. (2019) focus on phylogeographic patterns and the taxonomy of two intricate groups: Tephroseris longifolia agg. and Arabidopsis halleri, respectively. Using a wide range of molecular markers and multivariate morphometric analysis, the authors provide taxonomic and biogeographic treatment of the infraspecific variation of both groups in the Carpathians and adjacent regions (the Alps, the Balkans and the Hercynian Massif). In a similar spatial context, the role of the Carpathians as an important glacial refugium and their connections with neighbouring areas are highlighted by a study on Doronicum austriacum (Stachurska-Swakoń et al. 2020). These results, presented in a comparative framework, offer new insights into the phylogeographic patterns of species building subalpine tall-herb communities. The phylogeographic break between the Western and the South-Eastern Carpathians and the close affinity between the Western Carpathian and Sudetes populations appeared as the most significant features shared by all of the so far studied species belonging to the tall-herb plant communities.

Macková et al. (2020) and Mered'a et al. (2019) contribute to the better understanding of a rather complex cytogeography of the Western Carpathians (see Mráz and Ronikier 2016) and present comprehensive cytogeographical surveys in Cotoneaster and Sesleria, two morphologically variable and taxonomically intricate genera. Spatial patterns of ploidy and genome size variation found in both groups challenge previous taxonomic concepts and clarify the geographical distribution of taxa. These papers demonstrate the usefulness of flow cytometric approach for rapid and accurate ploidy level and genome size assessment thus providing an important tool for discrimination of closely related taxa.

Recent studies on ecological drivers of the Carpathian biodiversity are pictured by a case study of peculiar, isolated habitats, namely 19 saline lakes in the Transylvanian Basin. Spatial structure and taxonomic diversity of the phototrophic primary producer communities that inhabit these extreme saline environments are explored by Şuteu et al. (2021). The authors highlight that, contrary to their initial hypothesis, not salinity but habitat heterogeneity, together with nutrient availability, constitute the main drivers of taxonomic diversity in the investigated lakes. In addition, their results show that local phototrophic communities are characterised by the presence of rare taxa in more than $60 \%$ of cases, challenging the expectation that these algal communities are entirely composed of widespread ecological specialists.

Finally, one paper featured in this special issue does not provide original data but rather an important research perspective. Breman et al. (2020) outline a new, international project launched by the Carpathian Research Network (CRN), an international consortium (involving researchers from Czechia, Slovakia, Poland, Ukraine, Hungary, Romania and France) that endeavours to overcome previous drawbacks of country-specific research and conservation activities that limited data sharing and maintained contrasting chorological and taxonomic knowledge among neighbouring Carpathian countries. In the present time, when climate change poses a higher than ever need of understanding the larger picture of biodiversity patterns by accessing big datasets (Franklin et al. 2017), this initiative appears highly needed to provide an adequate framework for effective assessment of the Carpathian biodiversity. Among the main goals, the CRN aims to produce the first comprehensive taxonomical and biogeographical synthesis of the Carpathian endemic vascular flora, to better understand the underlying processes involved in its evolution and distribution, and to improve its conservation.

The Guest Editors would like to thank the Editor-in-Chief Karol Marhold, for the invitation to publish this topical collection in Plant Systematics and Evolution. We particularly thank Barbora Šingliarová and Katarína Skokanová for their excellent editorial assistance.

\section{References}

Aeschimann D, Lauber K, Moser DM, Theurillat J-P (2004) Flora alpina, vol 1-3. Haupt, Bern

Bálint M, Ujvárosi L, Theissinger K, Lehrian S, Meszáros N, Pauls SU (2011) The Carpathians as a major diversity hotspot in Europe. In: Zachos F, Habel J (eds) Biodiversity Hotspots. Springer, Berlin, p 189. https://doi.org/10.1007/978-3-642-20992-5_11

Breman E, Hurdu B-I, Kliment J, Kobiv Y, Kučera J, Mráz P, Puşcaş M, Renaud J, Ronikier M, Šibík J, Schmotzer A, Štubňová E, Szatmari P-M, Tasenkevich L, Turis P, Slovák M (2020) Conserving the endemic flora of the Carpathian region: an international project to increase and share knowledge of the distribution, evolution and taxonomy of Carpathian endemics and to conserve endangered species. Pl Syst Evol 306:59. https://doi.org/10.1007/ s00606-020-01685-5

Coldea G (2003) The alpine flora and vegetation of the Romanian Carpathians. In: Nagy L, Grabherr G, Körner C, Thompson D (eds) Alpine biodiversity in Europe. Springer, Berlin, pp 65-73

Franklin J, Serra-Diaz JM, Syphard AD, Regan HM (2017) Big data for forecasting the impacts of global change on plant communities. Global Ecol Biogeogr 26:6-17

Jablonski D, Jandzik D, Mikulíček P, Džukić G, Ljubisavljević K, Tzankov N, Jelić D, Thanou E, Moravec J, Gvoždík V (2016) 
Contrasting evolutionary histories of the legless lizards slow worms (Anguis) shaped by the topography of the Balkan Peninsula. BMC Evol Biol 16:99. https://doi.org/10.1186/ s12862-016-0669-1

Jarčuška B, Kaňuch P, Nad'o L, Krištín A (2019) Quantitative biogeography of Orthoptera does not support classical qualitative regionalization of the Carpathian mountains. Biol J Linn Soc 128:887-900. https://doi.org/10.1093/biolinnean/blz143/5585928

Juřičková L, Horáčková J, Jansová A, Kovanda J, Harčár J, Ložek V (2019) A glacial refugium and zoogeographic boundary in the Slovak eastern Carpathians. Quatern Res 91:383-398. https://doi. org/10.1017/qua.2018.68

Macková L, Nosková J, Ďurišová L, Urfus T (2020) Insights into the cytotype and reproductive puzzle of Cotoneaster integerrimus in the Western Carpathians. Pl Syst Evol 306:58. https://doi.org/10. 1007/s00606-020-01684-6

Melichárková A, Španiel S, Marhold K, Hurdu B-I, Drescher A, Zozomová-Lihová J (2019) Diversification and independent polyploid origins in the disjunct species Alyssum repens from the Southeastern Alps and the Carpathians. Amer J Bot 106:1499-1518. https:// doi.org/10.1002/ajb2.1370

Mered’a P, Majerová M, Somlyay L, Pekárik L, Hodálová I (2019) Genome size variation in the Western Carpathian Sesleria (Poaceae) species. Pl Syst Evol 305:845-864. https://doi.org/10. 1007/s00606-019-01622-1

Mráz P, Ronikier M (2016) Biogeography of the Carpathians: evolutionary and spatial facets of biodiversity. Biol J Linn Soc 119:528-559. https://doi.org/10.1111/bij.12918

Ozenda P (1985) La végétation de la chaîne alpine dans l'espace montagnard Européen. Masson, Paris

Pârvulescu L, Pérez-Moreno JL, Panaiotu C, Drăguţ L, Schrimpf A, Popovici I-D, Zaharia C, Weiperth A, Gál B, Schubart CD, Bracken-Grissom H (2019) A journey on plate tectonics sheds light on European crayfish phylogeography. Ecol Evol 9:19571971. https://doi.org/10.1002/ece3.4888

Puşcaş M, Choler P (2012) A biogeographic delineation of the European Alpine System based on a cluster analysis of Carex curvula-dominated grasslands. Flora 207:168-178. https://doi.org/ 10.1016/j.flora.2012.01.002

Ronikier M (2011) Biogeography of high-mountain plants in the Carpathians: an emerging phylogeographical perspective. Taxon 60:373-389. https://doi.org/10.1002/tax.602008

Schmitt T (2009) Biogeographical and evolutionary importance of the European high mountain systems. Frontiers Zool 6:9. https://doi. org/10.1186/1742-9994-6-9

Skokanová K, Šingliarová B, Kochjarová J, Paule J (2019) Nuclear ITS and AFLPs provide surprising implications for the taxonomy of Tephroseris longifolia agg. and the endemic status of T. longifolia subsp. moravica. Pl Syst Evol 305:865-884. https://doi.org/10. 1007/s00606-019-01624-z

Šrámková G, Kolář F, Záveská E, Lučanová M, Španiel S, Kolník M, Marhold K (2019) Phylogeography and taxonomic reassessment of Arabidopsis halleri: a montane species from Central Europe. Pl Syst Evol 305:885-898. https://doi.org/10.1007/ s00606-019-01626-x

Šrámková-Fuxová G, Záveská E, Kolář F, Lučanová M, Španiel S, Marhold K (2017) Range-wide genetic structure of Arabidopsis halleri (Brassicaceae): glacial persistence in multiple refugia and origin of the Northern Hemisphere disjunction. Bot J Linn Soc 185:321-342. https://doi.org/10.1093/botlinnean/box064

Stachurska-Swakoń A, Cieślak E, Ronikier M, Nowak J, Kaczmarczyk A (2020) Genetic structure of Doronicum austriacum (Asteraceae) in the Carpathians and adjacent areas: toward a comparative phylogeographical analysis of tall-herb species. Pl Syst Evol 306:14. https://doi.org/10.1007/s00606-020-01652-0

Stevanović V (1996) Analysis of the Central European and Mediterranean orophytic element on the mountains of the W. and Central Balkan Peninsula, with special reference to endemics. Bocconea 5:77-97

Şuteu AM, Momeu L, Battes KP, Baricz A, Cristea A, Bulzu PA, Buda DM, Banciu HL, Cîmpean M (2021) Diversity and distribution of phototrophic primary producers in saline lakes from Transylvania, Romania. Pl Syst Evol 307:12. https://doi.org/10.1007/ s00606-020-01733-0

Tkach N, Röser M, Suchan T, Cieślak E, Schönswetter P, Ronikier M (2019) Contrasting evolutionary origins of two mountain endemics: Saxifraga wahlenbergii (Western Carpathians) and S. styriaca (Eastern Alps). BMC Evol Biol 19:1-19. https://doi.org/10.1186/ s12862-019-1355-x

Wielstra B, Zieliński P, Babik W (2017) The Carpathians hosted extraMediterranean refugia-within-refugia during the Pleistocene Ice Age: genomic evidence from two newt genera. Biol J Linn Soc 122:605-613. https://doi.org/10.1093/biolinnean/blx087

Zając KS, Proćków M, Zając K, Stec D, Lachowska-Cierlik D (2020) Phylogeography and potential glacial refugia of terrestrial gastropod Faustina faustina (Rossmässler, 1835) (Gastropoda: Eupulmonata: Helicidae) inferred from molecular data and species distribution models. Organisms Diversity Evol 20:747-762. https:// doi.org/10.1007/s13127-020-00464-x

Publisher's Note Springer Nature remains neutral with regard to jurisdictional claims in published maps and institutional affiliations. 